\title{
Propagation in the Conditions of In Vitro of Fruit and Berry Cultures for Conservation and Restoration Ancient Forms of Plants
}

\author{
Bekkuzhina S.S., Mukhtubaeva S.K., Bugubay G.Zh., Sitpayeva G.T.
}

\begin{abstract}
Micropropagation of ancient plant forms and their accelerated replication for the purpose of creation of a basis of selection of fruit and berry cultures is a relevant task. For development of selection of fruit and berry cultures in the conditions of northern Kazakhstan, and for gardening improvement, local forms of plants are entered into the culture of in vitro. Test tube plants of cherry, currant, apricot are received. Various options of the MS environment with addition of the gibberelic acid (GA) in combination with the ascorbic acid (AA) are optimized. It is revealed that addition of gibberelic acid and ascorbic acid in concentration of $3 \mathrm{mg} / \mathrm{l}$ is more effective for propagation of blackcurrant.

Key words: in vitro propagation, BAP-6 Benzylaminopurine, GA-gibberellic acid, commercial culture cherry, currant, apricot.
\end{abstract}

\section{INTRODUCTION}

The resolution of the government of the Republic of Kazakhstan, of February 27, 2015 No. 4-1/168, defines the strategy of our Republic and relevance of problems, and search of new decisions on cultivation of commercial cultures [1].

Cultivation of domestic grades of fruit and berry cultures is generally carried out in the south of Kazakhstan. Use of biotechnological methods allows to advance cultivation of fruit and berry cultures and to the north Kazakhstan.

Now one of effective instruments of biotechnology of plants is micropropagation. Micropropagation is widely used for industrial production of fruit and berry [2, 3, 4, 5], decorative cultures and herbs around the world. Especially this method is important at propagation of rare endangered endemic species and also for the accelerated propagation and conservation ancient forms of plants.

One of the strategic objectives of fruit breeding is the revival and conservation of the unique properties of the famous aport.

Revised Version Manuscript Received on October 20, 2019 * Correspondence Author

Bekkuzhina S.S*., S.Seifulin Kazakh Agrotechnical University, NurSultan, Kazakhstan, email: sara-bek@yandex.ru

Mukhtubaeva S.K., Branch of the Botanical Garden of Nur-Sultan, Nur-Sultan, Kazakhstan, email:mukhtubaeva@mail.ru

Bugubai G.Zh., S.Seifulin Kazakh Agrotechnical University, NurSultan, Kazakhstan, email: gulaina.bugubai@mail.ru

(C) The Authors. Published by Blue Eyes Intelligence Engineering and Sciences Publication (BEIESP). This is an open access article under the CC BY-NC-ND license (http://creativecommons.org/licenses/by-nc-nd/4.0/)
At the Institute of Biology and Biotechnology, a "new plant" of aport in vitro was obtained by microclonal propagation. In 2012-2014, the Institute of Fruit Growing and Viticulture (KazNIIPiV) carried out molecular genetic studies on the genotyping of 11 forms of the Sivers wild apple tree and aport.

In KazNIIZiKR in the mountains of the Dzhungarsky and Zailiysky Alatau, as well as Tarbagatai, about 30 forms of the Sivers apple tree were selected [6].

According to the statement of the famous selector A.I. Vavilov, one of important points of development of selection of plants is creation of a gene pool of local forms of plants [7].

Cornerstone for creation of bases of selection of fruit and berry cultures in the conditions of northern Kazakhstan is the accelerated propagation ancient forms of plants, their replication by means of micropropagation.

The purpose of this work introduction to the culture of in vitro of local forms of fruit and berry plants and creation of a collection in the conditions of the minimum growth and also receiving the microcrops exempted from endophytic and other types of an infection.

\section{MATERIALS AND METHODS}

Theoretical and applied aspects of micropropagation are described in many in many works of research character [8, $9,10]$ and also monographs and textbooks [11,12].

Now successful protocols and methodical features of cultivation of different types of vascular plants are detailed and described.

It is necessary to distinguish from a set of advantages of micropropagation especially improvement the test tube of plants from a viral, mushroom and bacterial infection [13].

As objects of researches used local forms of fruit and berry cultures: currants, cherries, raspberries, the apricot growing in the city of Nur-Sultan and nearby regions.

Collecting plant material for introduction to the culture of explant was carried out in 2 steps in the spring and in the fall. The beginning of collecting in the fall - the end of September and October, buds in a condition of deep rest, and in the spring when buds did not waken from winter rest and also the dismissed first leaves.

At a stage of introduction to the culture of in vitro the sterilizing agents used: $\mathrm{Na}$ hypochlorite, antibiotics (ampicillin, etc.), potassium permanganate and also antioxidant substances. 
Sterilization of plant material was carried out according to generally accepted methods [14].

Buds separated from wood and washed out in flowing water 3 times; washed out $\mathrm{KMnO}_{4}$ within 5 minutes; washed $70 \%$ with solution sodium hypochlorite within 20 minutes. When using of the sprouted buds used $50 \%$ sodium hypochlorite solution within 15 minutes.

Cultivation of microshoots carried out in conditions - the photoperiod 16/8 illumination the 5000th luxury, temperature $23 \pm 3{ }^{\circ} \mathrm{C}$ and humidity of $70 \%$. The analysis of culture was carried out every 2 week and in 3-4 weeks culture was replaced to fresh nutrient medium.

For increase in efficiency of micropropagation added to the Murasige-Skuga environment (MS): cytokines: BAP-6 Benzylaminopurine -0.5 and Indole acetic acid (IAA)-0.5. GA used in combination with AA, options of nutrient mediums: - GA 0.5 mg; GA 1 mg + AA- 1 mg; GA 3 mg + $3 \mathrm{mg}$ of AA. As control option of a bud and a meristem cultivated on the MS environment without hormones.

\section{RESULTS OF RESEARCHES}

It is known that micropropagation, with use of a meristem as the explant, is effective and the frequency of an exit of sterile culture is higher for many cultures, apical sites of buds and sheet explant give vent the low test tube of plants.

Our pilot studies will be coordinated with data of references, induction of shoots of currant and cherry, shown in table 1 shows that forth putting is higher when as the explant used meristems (79.2\%).

Unfortunately, in our pilot studies when using sheet explant, their further development, did not yield significant results. For example, for the culture of currant growth was suspended completely, and for cherry sprout-formation left $17.5 \%$.

Table- I. Micropropagation of culture of currant and cherry

\begin{tabular}{|c|c|c|c|}
\hline Plant species & $\begin{array}{c}\text { Explan } \\
\text { t types }\end{array}$ & $\begin{array}{c}\text { Number of } \\
\text { explants,pc }\end{array}$ & Seedlings, \% \\
\hline \multirow{2}{*}{ Currant } & Meristem & 120 & 79,2 \\
\cline { 2 - 4 } & Buds & 83 & 48,2 \\
\cline { 2 - 4 } & leaves & 80 & 0 \\
\hline $\begin{array}{c}\text { The } \\
\text { coefficient of } \\
\text { variation }\end{array}$ & & $94,3 \pm 0,19$ & $42,46 \pm 0,76$ \\
\hline Cherry & Meristem & 158 & 62,1 \\
\hline & Buds & 65 & 46,2 \\
\hline & leaves & 57 & 17,5 \\
\hline $\begin{array}{c}\text { The } \\
\text { coefficient of } \\
\text { variation }\end{array}$ & & $93,3 \pm 0,48$ & $41,9 \pm 0,15$ \\
\hline
\end{tabular}

From explant of buds an exit of sterile culture is lower, than in meristemic culture and made 48.246 .2 for cherry and currant respectively. From sheet explant shoots did not develop further.

From the sprouted buds of an apricot sterile culture, as shown in fig. 1 is also received, education pass bushes with leaf-bearing shoots.
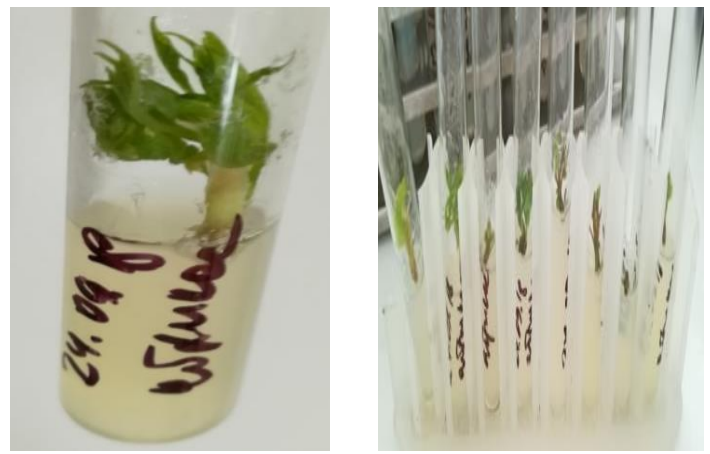

Fig. 1. Sterile apricot culture on MS medium

In numerous researches the key role of phytohormones is noted, at a stage of obtaining sterile culture considerable influence is rendered by exogenous auxins. For example, from cowberry ordinary the greatest number of actively growing shoots is received at cultivation on the WPM environment containing $4 \mathrm{mg} / \mathrm{l}$ of IAA[15].

In our pilot studies without addition of GA on net propagation of culture were located as follows: apricot-1.25. cherry - 1.5 currant 1.9 of fig. 2 .
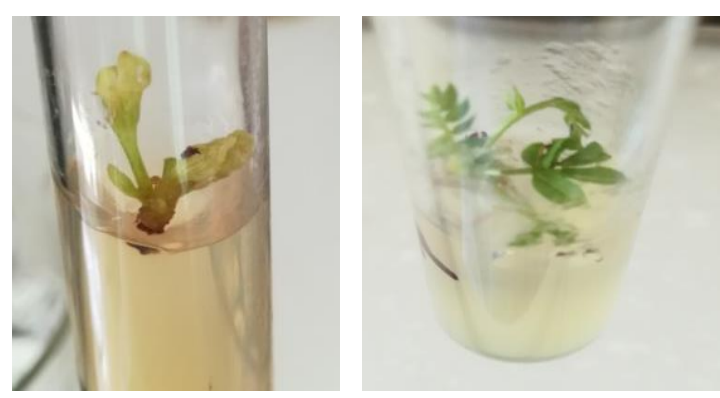

Fig. 2. Test plants on MS medium without gibberellic acid

Especially the importance, at cultivation of fruit and berry, has use of gibberelic acid for example, for currant. It is expedient to carry out cultivation of primary explant of blackcurrant on the medium containing in addition to cytokinin and auxin and gibberelic acid (concentration of $0.5 \mathrm{mg} / \mathrm{l}$ is most effective) [16].

At modification of a medium with different concentration of gibberelic acid it is revealed that increase in concentration of substance positively influences growth of shoots.

As shown in figure 3 obtaining sterile culture of shoots in meristematic culture was more effective on versions of the MS GA 2 - 3 mg/l.

Gradual increase in concentration, maybe, would also lead to further increase in germination of shoots, from the landed explant and to emergence of plants with several shoots, but growth of cells stretching it is dangerous by development of thin and fragile shoots. 


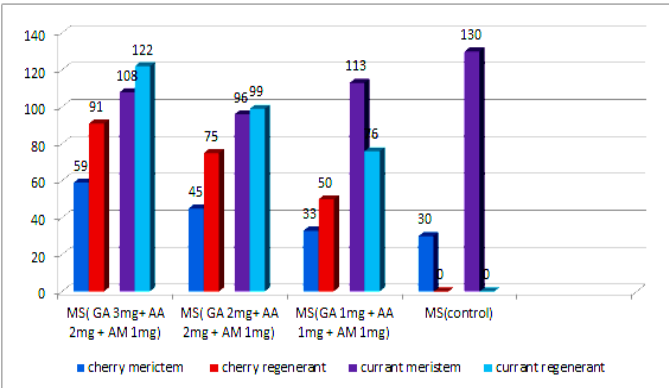

Fig. 3. Development of primary shoots with the addition of GA

According to these fig. 3 it is possible to observe that at GA addition primary sprout-formation for the culture of currant is higher, than for cherry. In all pilot studies further development of plants was better for currant in comparison

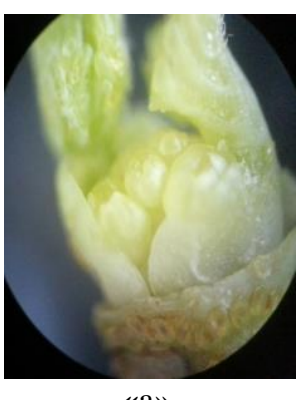

«a»

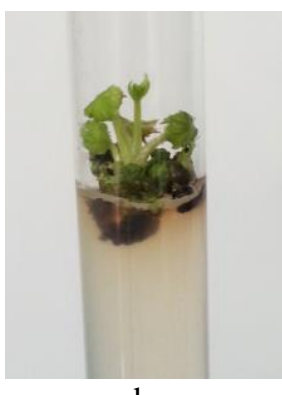

«b»

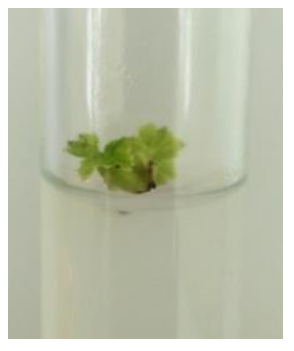

«C»

Fig. 4 Types of development of test-tube currant plants: a) meristemic culture; b) stretching the primary shoots; c) the development of small bushes

Thus, cultivation on the Wednesday with GA is effective, but in order to avoid emergence the veterified of shoots can result further increase in concentration of GA in negative effect.

\section{CONCLUSION}

So, for creation of a basis of selection of fruit and berry cultures it is necessary to have a collection of local forms of the plants long since burgeoning in this region i.e. it is not obligatory to have the zoned grades, and then on their basis to create the zoned grades.

At initial stages it is necessary to microtype, and then to store in conditions of the minimum growth and further to carry out genetic certification. All this is an important condition for creation of effective selection of commercial cultures.

\section{REFERENCES}

1. https: //online.zakon.kz/document/ Doc_id $=31580673 \#$ pos $=19 ;-45$ with other fruit crops of fig. 4.

2. Khromova, T. M. et al. Use of biotechnological techniques in the reproduction of black currant. Bulletin of the Russian Agricultural Science, N 6, pp. 69-73, 2019: http: //www.vestnik

3. J. Juan - Vicodo, J. Luis Casas - Martinez. Micropropagation of economicalli important, wild and endemic species of Lapiedra and Narcissus Amaralidiaceae as bases for their concervation and industrial production in Spain" / Advances in Chemistry and Chemical Technology Vol. 31, 2017, No. 2, pp. 36-38

4. Stanisavljević, D. Bošnjak, I. Štolfa, R. Vuković, T. Kujundžić, M. Drenjančević Sterilization of different explant types in micropropagation of cab-6P and Gisela cherry rootstock // Poljoprivreda. - 2017

5. Juran Chandra Goyali B. Characteristics of in vitro- and ex vitroPropagated blueberry plants at morphological, chemical and molecular levels // Department of Biology Memorial University of Newfoundland, Canada. - 2018.

6. https://newtimes.kz/obshchestvo/15436-znamenityj-aportvozrozhdayut-v-kazakhstane

7. Vavilov N. I. Centers of origin of cultivated plants // Transactions on Prikl. bot., gene. and sat down. L.: VIR. - 1926. - V. Vol. 16, No. Issue 2, pp. 52.

8. Jiri Sedlak. Frantisek Paprstein Micropropagation of highbush blueberry cultivars // research and Breeding Institute of Pomology Holovousy Ltd., 50801 Horice, Czech Republic, - 2018.

9. Riitta Törrönen, Jarkko Hellström, Pirjo Mattila and Kyllikki Kilpi Postprandial glycaemic response to berry nectars containing inverted sucrose // Department of Clinical Nutrition, Institute of Public Health and Clinical Nutrition, University of Eastern Finland, Journal of Nutritional Science 2017.

10. T.R. Anchondo, J.A. Martínez, T. C. Castillo, R. Ángel Parra Quezada, D. Leopoldina Ojeda Barrios, A.H. Rodríguez In vitro establishment of two cultivars released from strawberries: strawberry and raspberry // Revista Mexicana de Ciencias Agrícolas volume 9 number 4 May 16 Jun 29, 2018

11. Butenko R.G. Biology of cells of higher plants in vitro and biotechnology based on them, Textbook, M.1999, pp. 158

12. L.V. Nazarenko, Yu.I. Dolgikh, N.V. Zagoskin, G.N. Raldugina Biotechnology plants: textbook and prakt. for undergraduate and graduate programs / 2nd ed., rev. and add. - P.: Yurayt Publishing House, 2018, pp. 161.

13. N.V. Romadanova, N.A. Seraj, M.M. Nurmanov, L.N. Karasholakova Introduction to the in vitro culture of the wild apple tree Malus sieversii // Research, results. No. 3 (75) 2017

14. E.A. Kalashnikova, E.Z. Kochiev, O.Yu. Mironova Workshop on Agricultural Biotechnology for Students // P.: Kolos, 2006.

15. Hussey G. In vitro propagation of monocotyledonous bulbs and corms // In: Proceedings of the 5th International Plant Tissue and Cell Culture.Tokyo, 1982, pp. 677-680

16. I.A. Raikov Improving the clonal micropropagation of interspecific forms of blackcurrant and raspberry of the remontant type. // Bryansk, 2012, pp. 19

\section{AUTHORS PROFILE}

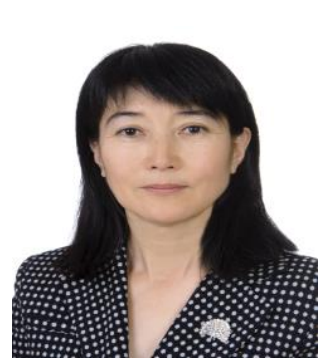

Name: Sara Bekkuzhina

Phone: 8 (7172) 396-167

E-mail: sara-bek@yandex.ru

Education: PhD Russian State Agrarian University - MTAA named after K.A.Timiryazev, The Faculty of Agronomy, 2011.

Dissertation: "Application of Haploid technology in rapid creation of initial forms and drought-resistant soft wheat stable to Septoria nodorum Berk."Committee: The Academic Council (31 professors and academicians, specialists on plant biotechnology field).

PhD student of biotechnology department , Russian State Agrarian University - MTAA named after K.A.Timiryazev, Moscow, Russian Federation, 1990-1993.

Internship in Lomonosov Moscow State University and Timiryazev Institute of Plant Physiology, Russian Academy of Sciences, 1988-1990.

Research experience:

Scientific project, Ministry of Agriculture of the Republic of Kazakhstan, 2000-2005

\section{Published By:}

Blue Eyes Intelligence Engineering

\& Sciences Publication

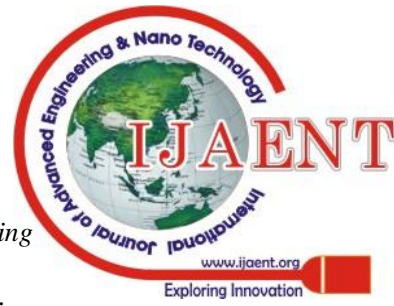




\section{Propagation in the Conditions of In Vitro of Fruit and Berry Cultures for Conservation and Restoration Ancient Forms of Plants}

- $\quad$ The extension of soft wheat genetic basis with DH-method. Scientific project, Center of Biological Researches of Ministry of Education and Science of the Republic of Kazakhstan, 2006-2008

- The improvement of wheat selection methods at the cell level, elucidation of the mechanisms which provide the resistance to biotic factors in morphogenetic cycle of cell - plant -cell. 2008

Scientific project, International Science and Technology Center, 2003-

- Phytoremediation of polluted soils in Kazakhstan

Scientific program, 2013-20014

- The creation of Kazakh-Australian plant functional genomics center.

Teaching Experience: .Seifullin Kazakh Agro Technical University, 62 Prospect Pobedy, Astana, Republic of Kazakhstan

Associate Professor, Microbiology and Biotechnology Department, 2014

- Taught Plant Biotechnology, Environmental Biotechnology an undergraduate course averaging 100 students per semester.

- Taught Molecular and Genetic Bases of Biotechnology a graduate course with 14 students per semester.

- Coordinated grading and labs with a team of 4 teaching assistants Ph.D. candidate, Plant selection and biotechnology department, 2005-2008

S.Seifullin Kazakh Agro Technical University, 62 Prospect Pobedy,

Head of the department, Department of physiology and plant biotechnology, 2005-2008

\section{Publications: Books:}

Bekkuzhina, S.S., Plant biotechnology, 2009.

Bekkuzhina, S.S., From microspore to plant selection, 2014.

Bekkuzhina, S.S., Genetic Engineering tutorial, 1999.

Journal Publications:

Bekkuzhina S.S, Botayeva M., Zhamekova A, Ospankulova G,

K.R. Urazaliyev

Possibilities of use of Gamete Breeding for

Selecting of Plants Resistant to Water Deficiency

International Journal of Advanced Engineering and Nano

Technology (IJAENT) ISSN: 2347-6389, Volume-3 Issue-3, April 2016 IF

2.04 http://ijaent.org/v3i3.php

Botayeva M.B., Zhamekova A.M., Bekkuzhina S.S.

Using possibilities of in vitro methods for enrichment of fodder balance of alfalfa . The Way of Science International scientific journal, № 4 (26), 2016 IF 0,5 www.scienceway.ru ISSN 2311-2158.

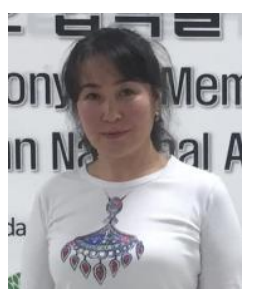

Name: Saule Mukhtubaeva

E-mail: mukhtubaeva@mail.ru

Position : Director of the Botanical Garden of Nur - Sultan Northern Tian Shan - The Kungey Alatau. //Korea, 2018. $-240 \mathrm{p}$

- Mukhtubaeva S.K. Konspekt flory vostochnoy chasti khrebta Kungey Alatau, Almaty, 2017- Tom 23 (11). - 271 s.

- Kubentaev S.A., Kotukhov Yu.A., Gemedzhieva N.G., Mukhtubaeva S.K. Sovremennoe sostoyanie populyaci redkikh lekarctvennyx rasteny Kazakhstanskogo Altaya // Mat.konf. Botanicheckie issledovaniya Sibiri I Kazakhstana.- Barnaul/ 2019 g.- Vypusk 25. - S. 102 111

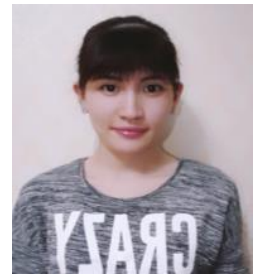

Name: Gulaina Bugubai

Phone: + 77072996112

E-mail: gulaina.bugubai@mail.ru

Education: Bachelor's degree in technical sciences, specialty "Biotechnology", Kazakh Agrotechnical University named after S.Seifullin, 2014-2018.

Currently I study in master 's degree of 2 courses in the specialty "Biotechnology", Kazakh

Agrotechnical University named after S.Seifullin.

Publications: Bekenova A.B, Bugubay G., Bekkuzhina S. Ispolzovanie vozmozhnostei kultury kletok I tkanei dlya polucheniya biopreparata $\mathrm{v}$ culture lucerny / Vishaya shkola MBA IntegraL Russko-Italyanskii mezhdunarodnyi universitet, Sovremennaya mirovaya economika: problem I perspectivy $\mathrm{v}$ epokhu razvitiya cifrovyz tekhnologi i biotekhnologi / Sbornyk nachnyx statei mezhdunarodnoi nachnoi konferencii (29-31 marta 2019 g.) Astana, Republic of Kazakhstan

Publications: - Mukhtubayeva S. Flora of the

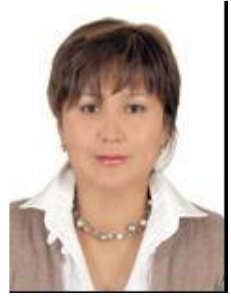

Name: Sitpayeva Gulnara

Affiliation: Institute of Botany and Phytointroduction, Ministry of Education and Science, Republic of Kazakhstan

E-mail address: sitpaeva@mail.ru

Brief introduction

\section{Date of birth: 19.09 .1966}

Nationality/Citizenship: Kazakhstan

Education: M.S. - Kostanay Pedagogical Institute, Kazakhstan (1989), PhD - Institute of Botany \&Phytointroduction, Almaty, Kazakhstan (1999), Dr. of Sciences (Ecology), Almaty, Kazakhstan, 2010.

Working Experience: 1989-1992 Teacher of Biology

1992-1995 Laboratory Assistant of the Department of Botany of

Kustanay Pedagogical Institute

1995-1996 Teacher of Department of Botany

1996-1998 PhD Student at the Institute of Botany and

Phytointroduction

1998-2005 Researcher of the Laboratory for Plant Resources

2005-2008 Academic Secretary of the "Institute of Botany and

Phytointroduction" of the Ministry of Education and Science of the

Republic of Kazakhstan

03.01.2008 - 17.09.2008 Head of Laboratory for Dendrology of the "Institute of Botany and Phytointroduction" of the Ministry of Education and Science of the Republic of Kazakhstan"

2008-2010 Acting Director of Institute of Botany and Phytointroduction 2010 - up to the present General Director

Publications: 6 monographs, more than 170 articles and theses, including in USA, France, Japan, Czech Republic, Bulgaria, Hungary, Greece, Germany, China, Korea, Turkey

Research experience: Participation in 6 international grants:

- National geographic society Washington, D.C. under the project "Modern and fossil flora of Turgai» (1995-1997);

- "Study of plants in Kazakhstan and collection of genetic resources of wheat and barley to improve crop selection" International center for improvement of wheat and corn (CIMMYT-Mexico, 2002-2003);

- "The study of the flora of steppes of the Ukraine, Kazakhstan and Mongolia" in cooperation with colleagues from the University of Tsukuba/Japan, 2004-2005);

- ISTC K-719P "Detection and identification of natural products from the flora of Kazakhstan for the agrobiological purposes" (2002-2007);

- University of Washington "To create new demonstration plots in the Main Botanical garden" (2010-2011);

- "Profile (zonal) study on climate change and its influence on ecosystems of arid lands in Central Asia" (Xinjiang Institute of Ecology and Geography, CAS, 2010-2012);

- Processing and cultivation of a licorice root in the territory of the Kyzylorda region " together with BIS-Group LLP» (2013 - 2014).

Supervising in programs supported by Ministry of Education and Science of Kazakhstan:

- Introduction enrichment of the gene pool of the Botanic gardens of Kazakhstan, the creation of the technology of domestication and breeding of plants (2008).

- Preservation, replenishment and development of collection funds of the Main Botanical garden (2008-2010).

- Development and creation of the exposition of the flora of Kazakhstan in the Botanical garden "Bagatelle "(France), as a prototype of the introduction of plants of Kazakhstan in the green building of Europe (20112013).

- Ensuring the preservation and development of collections of plants, animals, microorganisms, viruses and unique genetic banks as the basis of fundamental research (2012-2014).

- Botanical Diversity of Crop Wild Relatives in Kazakhstan as a Source for the Enrichment and Conservation of Agrobiological Diversity Genetic Fund for the Implementation of the Food Program (2013-2015).

- Sustainable development of genetic recourses of State Botanical Gardens in the South-east and Central Kazakhstan - nature reserves of strict protection of the Republic importance in the transition to a "green economy" (2015-2017).

- Implementation by the State Botanical Gardens of priority for Kazakhstan scientific and practical tasks of the Global Strategy for Plant Conservation as a sustainable system for maintaining biodiversity (20182020).

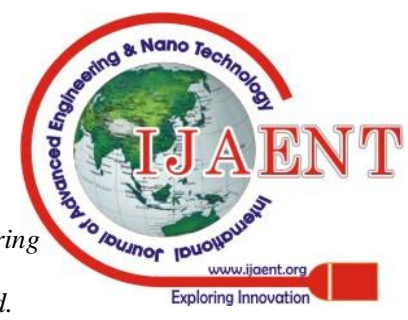

